\title{
UNDERSTANDING THE PUBLIC INTEREST IN DEVELOPMENT NYIA (NEW YOGYAKARTA INTERNATIONAL AIRPORT): AN ECONOMIC ANALYSIS AND LEGAL APPROACH
}

\author{
Muhammad Fikri Alan ${ }^{1}$ \\ ${ }^{1}$ Widya Mataram University, Yogyakarta \\ Email: mfikrialan@gmail.com
}

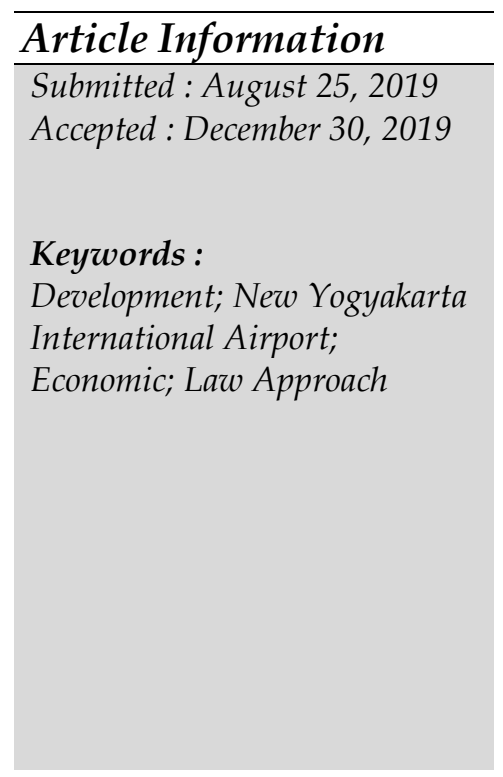

\begin{abstract}
This paper seeks to use economic and law approaches in looking at the problems that occur over the construction of New Yogyakarta International Airport (NYIA). According to the legal approach that is often done, it has not given a clear meaning of what the phrase "public interest" is. In fact, the meaning of this phrase becomes very important, considering that this is used as the basis by the state in seizing the right to land owned by people, which is then used for the construction of the airport. For the economic approach method, it is expected to be able to complete the approach, by analyzing whether the current development process can benefit the country economically or not. Thus, the use of economic approaches, in this case is the NYIA's development policy, in fact, can be ambiguous. On the one hand it can be a justification for the state to continue the development process. On the other hand, it can be a justification for the people who until now continue to expect the development of the NYIA to be halted.
\end{abstract}

\section{Introduction}

The conception of national agrarian law, declares that every land has a social function. This social function, bring down 3 main clauses. First, based on Explanation IV of Law Number 5 of 1960 concerning Basic Regulations on Agrarian Principles or UUPA, any land attached to a person cannot be justified that the land will be used (or not used) solely for his personal interests and give rise to loss for society. Second, based on Article 18 of the UUPA, when the state requires land for public purposes, including the interests of the Nation, the State and the People, land rights can be revoked by providing compensation. Third, as stipulated in Article 14 of the UUPA, the allocation of land rights held by the owner must be adjusted to the Spatial Plan determined by the Government.

The second derivation of the social function, gave birth to Law Number 2 of 2012 concerning Land Procurement for Public Interest (hereinafter referred to as the Land Acquisition Act). Based on Article 1 number 2 and 6 of this law, Land Acquisition activities can be carried out on the pretext of public interest, in the sense of the interests of the nation, state and society, carried out by the government, in order to realize the greatest prosperity of the people. Article 10 of the same law, then explains that there are 18 types of development activities, which can be categorized into land acquisition for public interest. As a result, when the state wants to develop under the pretext of public

Yustisia Volume 8 Number 3 (Sept.-Dec. 2019)

Understanding The Public Interest...

(C2019; This is an Open Acces Research distributed under the term of the Creative Commons Attribution Licencee (https://Creativecommons.org/licences/by/4.0), which permits unrestricted use, distribution, and reproduction in any medium, provided the original works is properly cited. 
interest and included in 18 types of activities, every citizen who has land on the object of public interest, must surrender his land after receiving sufficient compensation.

Problems arise when the impact of development in the public interest has become a source of structural agrarian conflict to this day. According to data from the Agrarian Reform Consortium (KPA), since the law was passed, at least on average there are 60 to 100 cases of agrarian conflicts caused by infrastructure development. Above all, 410 agrarian conflicts occurred during 2018 with an area of $807.177,6$ hectares. Although the number of conflicts has decreased than 2017 (659 agrarian conflicts), the area of conflicts has actually increased (from $520.491,87$ ha to $807.177,6$ ha). This condition, if taken on average, then every day there was an agrarian conflict and this number continues to grow. In addition, in 2017, from the number of land disputes above, the plantation reached the first rank of conflict with 208 amount of conflict. This number was followed by property conflicts which reached 199 cases, infrastructure 94 cases, and agriculture 78 cases. In 2018, plantation reached 410 conclict, properti 137 conflict, infrastructure 144 conflict, and agriculture 53 conflict. (KPA, 2012-2018)

Agrarian conflict as a result of the social function of land, is also evident in the New Yogyakarta International Airport (NYIA) development. The conflict actually has been started since 2011, nowadays it becomes more complicated and gets strong rejection from the society. The rejection was due to the airport construction permit issued by the Ministry of Transportation No. 1164/2013 dated 11 November 2013, which was considered not to involve the public. In fact, when the location permit was issued, the Head of BPN Regulation No. 2 of 1999 came into force regarding Location Permit. Article 6 of the regulation states that a location permit is granted after a coordination meeting is held between the relevant agencies, as well as the community holding the land rights in the requested location.

In addition, based on Article 19 of the Land Acquisition Law, public consultation is absolutely necessary and must be carried out in the preparation stage of land acquisition. This public consultation, carried out by involving the right parties and the people affected by the development for the public interest. Then, based on articles 21-23 Land Acquisition Act, if an agreement in the public consultation is reached regarding the location of the construction, a permit can be issued. However, in the event that the public consultation is rejected and no agreement is reached, there are other mechanisms regulated in the Land Acquisition Act to take legal action.

According to Mongabay records (Apriando, 2016), NYIA development was carried out without the public consultation. The community has never been involved in the process of determining and formulating locations, so permits are issued without opening up as much public participation as possible. In addition, the Environmental Impact Assessment (AMDAL) was not carried out properly. The AMDAL had not been completed until 2016, even though the Location Permit had been issued since 2013. In fact, according to Article 4 of Government Regulation Number 27 of 2012 about Environmental Permits, the AMDAL had to be carried out during the planning stage of a business activity. According to the provisions of article 14 of the Land Acquisition Law, the planning stage for infrastructure development activities must be carried out before the establishment of a location permit. Because, according to article 16, the determination 
of the location permit is in the preparation stage, where the preparation phase is carried out after the planning stage is completed.

Based on the entire description above, according to the author, location permits issued for NYIA development cannot be considered legal according to the law. Because they have not gone through the correct licensing process in accordance with statutory provisions. Even so, the construction of NYIA in fact continues to this day and leaves behind an unfinished structural agrarian conflict. This research, will look at the extent to which the development of NYIA which has been deemed legally flawed, uses an economic approach to the law and law approach. The economic approach model to the law is used to complete the legal analysis that has been carried out by legal experts in looking at the permit for the airport's construction site. In addition, in the second part, the legal approach to evaluate airport revenues as an object of public interest will also be explained. From the introduction above, a problem statement can be described: first, how is the Economic Approach in Developing the NYIA?; second, how is the Law Approach in Developing NYIA?

\section{Research Methods}

The research method with a normative juridical approach, prioritizes library research and its implementation in practice. Research specifications are descriptive. The research phase is carried out through library research, collecting secondary data in the form of primary, secondary, and field research materials to obtain primary data as a support.

\section{Research Result and Discussion}

\section{A. Economic Law and the Economic Approach to Law in Developing the NYIA}

At the beginning, there will be different understandings between economic laws and economic approaches to the law. The term on Economic Law is actually influenced by some of the terms contained in some western literature. The use of the term Economics Law, has several uses of other well-known terms, namely Economic Law, Economisch Recht, and a term known in US Law that uses the phrase Economic and Law (A. Mitchell Polinsky) or Bussines Law (Mark E. Roszkowski). The use of some of these terms is then summarized by some experts in Indonesia, in order to formulate an understanding of the meaning of economic law. According to Todung Mulya Lubis, for example, Economic Law is the entire law, customary law, and court decision related to economic activity, including legal entity of economic actors, transactions of economic actors, transactions of economic actors, to government intervention to support activities economic and including in it is mechanism of economic dispute resolution. (Sulistyono and Rustamaji, 2009)

Another notion of economic law is also presented by C.F.G. Sunaryati Hartono. According to her, economic law is the overall rules and legal decisions that specifically regulate the activities and economic life in Indonesia. The entire rules then result in the nature of the study of multi-disciplinary economic law which is not only limited to the Law of State Administration, but also regulates matters which include the substance of Criminal Law, Civil Law, Commercial Law, Private International Law, 
even Civil Procedure and Criminal. Sri Redjeki Hartono also expressed his opinion on the limits of economic law. According to him, economic law is "a series of rules governing economic activity undertaken by economic actors"(Hartono, 2003)

Based on these three meanings, according to the author in essence, economic law is a series of legal arrangements governing the life of the economy. As for the meaning of economic life can be a law on trade, cooperatives, agriculture, or other sectors regulated by law. So in essence, economic law is the law in general, but has its own peculiarities as it regulates the economic life of a country. The economic life can be a public economy that concerns the livelihood of the public, and may also be private legal arrangements in the economic field such as trade and purchase laws, as well as mortgage and guarantee rights.

This concept is different from the economic approach to the law. This method, according to Richard A. Posner, uses economic theories and methods, to analyze the law. Furthermore, Richard A. Posner states that The hallmark of the "new law and economics is the application of the theorities and empirical methods of economics to the central institustions of the legal system, including the common law doctrines of negligence, contract, and property; the theory and practice of punishment; civil, criminal, and administrative procedure; the theory of legislation and rulemaking; and law enforcement and judicial administration. (Posner, 1975)

By definition, it appears that an economic approach to law can be applied in various sectors of legal arrangements, such as contract and building law, and criminal law. In fact, economic approaches can also be used in relation to the effectiveness of sanctions, either in the form of imprisonment sanctions or administrative sanctions, as well as the legal process and testing the efficiency of law enforcement that has been and will be done. The whole approach sees from the economic perspective, and does not see only from the prevailing laws and regulations.

Another notion is also given by Cento Veljanovski. According to him, the economic approach is not limited to the laws governing the life of the economy. Instead, it uses the economy to see the law. Further Cento Veljanovski states that he want to reinforced the opinion of Richard Posner, regarding the importance of seeing the law of the economic perspective (Veljanovski, 2007). This is so that the law is not only understood in a false dimension, and apart from other values. This approach is also expected to provide other ideas, in assessing the validity of the law, in order to create more effective and efficient arrangements. Thus, the purpose of the formation of the law itself can be achieved.

Thus, there is a clear distinction between economic laws and the economic approach to law. Economic law should be seen as the law itself, whether in the form of legislation, judgment, or custom and custom law, which governs the life of a nation's economy. While the economic approach is to look at the law, from the perspective of theory and the methods contained in economics. Thus, the economic approach to the law is, in fact, a form of evaluation of the prevailing law, in order to achieve the objectives of the law itself.

As for the reasons for the choice of economic approaches to the law over economic law, it is actually apparent from the different understandings above. This 
paper seeks to test and evaluate the country's policies to build the NYIA. Whether indeed, from an economic perspective, the policy of the state is a favorable policy for the economy of the state and society, and an efficient policy in order to meet the needs and needs of the people's life, or is purely a form of misuse of the state in exercising its right to mastery natural resources.

Furthermore, in relation to the economic principles chosen in using the economic approach to the law are the principles of Costs and Benefits Analysis, and the principle of Assimetric Information. The reasons for using both approaches are:

1. Cost and Benefits Analyis is used to see the advantages and disadvantages of the establishment of NYIA from the economic perspective. Economic benefits will be seen from the state and local revenue perspective derived from the development of the NYIA, while the losses will be seen from the social cost, administrative cost, and opportunity costs. The use of this method of analysis is to achieve the highest economic efficiency;

2. Assimetric Information, will be used to see if the information in formulating the development of NYIA is correct or not. When the information provided is incorrect, it may result in market failures that may occur in the development process.

Both methods of this approach actually apply cumulatively. That is, when one of the two aspects is not met, then the economic development of the NYIA should be reviewed, because it can be considered ineffective and economically efficient. In the same way, when the two aspects can be met, then economically, the development of the NYIA can be considered feasible, and can be continued the process of development.

\section{Cost and Benefits Analysis}

Cost and Benefits Analysis can be termed as a profit and loss analysis, in fact it is often used by economists to assess policies related to limited resources. Or in other words, given the limitations of resources to be managed, any action taken on them should also be based on careful preparation. Therefore, this analysis is done, in order to avoid planning errors in any policy on the resources made.

As noted above, the advantages in this analysis will look at the country's acceptance of the development of the NYIA. In the case of the NYIA, state revenues are so great. This is evident from the investment provided by GVK Power Energy \& Infrastructure, a company from India to build this airport to reach 808 million USD (or reach 10.9 Trillion Rupiah). (www.centreforaviation. com) The profits that can be by the country with the amount is certainly very large. At least, the construction of this airport will not involve and burden the Regional Revenue and Expenditure Budget (APBN).

In addition to gains on financing the construction of the NYIA, the government will also benefit from the amount of taxes levied on airport operations. However, due to the limited scientific knowledge of the author, the amount of tax that may be obtained by the government can not be mentioned in 
this paper. Hopefully, there will be other writing that discusses the matter more comprehensively.

As for the loss analysis, will see from the cost perspective to be issued by the state. This cost is assumed as a loss, since it is included in state expenditure. Costs incurred, covering 3 main things, namely administrative costs (Administrative Cost), social costs (Social Cost), and loss of opportunity costs to utilize (opportunity cost) owned by the community. Analysis of these three aspects, will be done as follows:

\section{a. Administrative Cost}

According to Louis Kaplow and Stevan Shavell, administrative costs are the legal responsibility to be taken when engaging with the law. Furthermore, Stevan Shavell states that the administrative costs can be defined as the cost of land acquisition for the public interest (Kaplow and Shavell, 2002). The cost of land procurement is considered as an adverse cost, because it must be issued by the state, in this case PT. Angkasa Pura 1 as a state-owned company and airport developer. The amount spent on land acquisition costs is also counted as a large amount, considering the land required for the construction of the NYIA is 637 hectares. The amount issued by PT. Angkasa Pura 1 also reached Rp. 4,146 Trillion. According to this analysis, since the total amount of funds disbursed by the government to build airports is 10.9 Trillions (the result of investment from GVK Power Energy \& Infrastructure, then from administrative cost perspective, the government is still considered "benefit"

b. Social Cost

Social cost is actually the cost to be incurred by a company or business actors that impact on other parties outside of himself. R.H Coase explains in detail about the concept of Social cost. Furthermore, R. Coase states that social cost is used to compensate for the social and environmental impacts of a development project (Coase, 1960). In connection with the development of NYIA, PT. Angkasa Pura 1 should also think about this social cost. This is due to so many environmental and social impacts caused by the development of the NYIA. These impacts include land conversion that should be used for agriculture, to be used for airports, and the impact of changing spatial plans that should be used as anti-tsunami areas. This certainly has an impact on the social life of the people around the airport, as well as the communities directly affected by the airport development, as well as the environment in the region. There should be a cost to be taken into account by the government to address this.

The problem of the amount of costs that must be incurred, can not be detailed further in this paper, due to the need for further research to see it. However, the point to be explained is that the costs incurred by the government should increase as well. This also resulted in losses for the government as airport developers. 
The opportunity cost is the cost to be paid by the government, for losing the land management opportunity used for the development of the NYIA. Related to this, Cento Veljanovski states that the opportunity cost is actually related to the land procurement process for the construction of the airport (Veljanovski, 2007). For example, the land is ideally worth selling Rp. $1,000,000$ per square meter, because there is an opportunity cost that must be paid by the government, then the price goes up Rp. 2,000,000 per square meter. Opportunity cost in this case is used because after the compensation process, the landowner has no rights to the land, thus followed by loss of opportunity also to get the benefit of the land.

The concept of opportunity cost is indeed not binding in principle, because basically the new will be used in terms of requested by people who sell a good or service. However, given the current state of affairs, where communities are experiencing a great deal of resistance to the development of the NYIA, the concept of opportunity cost is likely to be taken into account in making an analysis of land valuation. When the opportunity cost is included in the land valuation process, the selling price becomes high, so it is hoped that the people who initially refuse to build the airport will be willing to give up their ownership of the land. Nevertheless, the use of this opportunity cost can also increase the amount of expenditure made by the government, resulting in additional losses in the analysis of cost and benefit analysis.

Based on the above three analyzes, it is not known exactly how much the government should pay to overcome the losses incurred as a result of the development of the NYIA, due to limited scientific and data owned by the author. However, in general it can be said that the government suffered losses on the development of NYIA, because there are many costs to be incurred by the government, in addition to funds for the construction and procurement of land. These costs are social cost and opportunity cost that must be paid by the government. Financing gained by the government to build NYIA is so great. However, whether the amount can meet the costs that must be spent earlier, there is no definite figure. In addition, state income on taxes also can not be calculated. Nevertheless, based on this analysis, in general, indicates that the country is inefficient from the economic perspective, on the development of the NYIA.

Economic efficiency is basically by making the smallest sacrifice, but get the maximum profit. This is not achieved, as it is abstractly, it is seen that the profits that the state can possibly get are "only" on funding gains, and tax advantages. Meanwhile, the costs incurred (which are the losses of the state), covering 3 aspects, namely administrative cost, social cost, and opportunity costs. Although it is not yet known how many of these advantages and disadvantages, it can be concluded that economic efficiency is not achieved, because the aspect of public expenditure or losses is more (3 aspects) than profit aspect ( 2 aspects). 


\section{Assimetric Information}

Assimetric Information, otherwise known as asymmetric or unbalanced information, according to the authors is the core issue of land acquisition for the development of the NYIA. The unbalanced information, in fact, results in market failure. According to the economic perspective, Assimetric Information is imperfect information and ignorance can cause the market to operate imperfectly and consumers and others to make wrong choices and actions. Further, information has public good characteristics so that there may be market failure in its production since is often difficult for those investing in better and new information to capture the financial returns. (Veljanovski, 2007)

AssimetricInformation thatoccurred inLandProcurementfor theconstruction of NYIA is under the pretext of the government, the cost of compensation for the land has been secured through a consignment mechanism to the Wates District Court. So, because they feel have done the process of compensation, then the government, in this case PT. Angkasa Pura 1 feels entitled to evict the house or yard on the land of the development of NYIA. However, residents who do not get the invitation or money from the compensation, feel it is not time to leave the house and yard. Thus, citizens are still trying to maintain their control over the land, and this leads to conflicts between citizens and developers. (www.tirto.id)

In addition, asymmetric information also occurs in the case of claims from the Sultanate of Yogyakarta, which states that the land of the 137-hectare NYIA land is owned by Pakualaman (PAG / Pakualaman Ground). In fact, the community has managed the land, which is mostly used as a pond, hotel and villa for tourism. The existence of such claims, resulted in the people who actually controlled the land of PAG, became unconfirmed, as compensation was granted to Pakualaman.

These unbalanced information, resulting in market failures, also result in errors in formulating conflict policies and measures. From an economic perspective, unbalanced market and information failures should be avoided, in order to eliminate any possible economic losses, either by the community (perceived as the seller of land) and PT. Angkasa Pura 1 (which is perceived as a land buyer). Therefore, economically, the unilateral action of eviction by the developer is wrong, because it is based on unbalanced information and market failure.

In closing, according to the authors, It is acceptable if the government really want to create an airport that can meet the needs of flights in Yogyakarta This policy will make this city as a city of better tourist destinations. But, it would be wise to the government if the policy chosen is to build and repair airports has been there, namely Adi Sutjipto Airport. The following economic analysis can be applied also in the renovation of Adi Sutjipto Airport:

a. The development process will not require much cost for land procurement, since most airport buildings already exist, so only need to be expanded (reducing the number of administrative costs and opportunity costs); 
b. Costs required for social and environmental impacts are not too large, since the area is initially used for the airport area (reducing social cost);

c. There will be no asymmetric information and market failures, since it is only necessary to change the ownership of the airport, from the original one to the military airport, to the airport for commercial purposes;

\section{B. Law Approach in Developing NYIA}

Law, in this research is constructed as a law that should be able to change society. According to Soerjono Soekanto (Soekanto, 1980) the law is very possible to make social changes. A social change in question is a social change that is desired or planned and carried out under the pioneers of change. For example the law is present as a tool to change people's obedience behavior towards the law, because the law is made equipped with strict sanctions. A social change occurred in the community which was initially "vigilante" into a submissive and peaceful society. This concept is often referred to Law as a tool of social engineering.

However, it also needs to be emphasized that legal changes and social change do not always have to go in harmony. The two do not have to walk together, in the sense of influencing one another. According to Daniel S. Lev (Lev, 1971) in society, what is considered as law is the practice and behavior of legal officials. Thus, if the behavior of legal officials including judges, prosecutors, lawyers, and the police in general changes, then the law is considered to have changed even though norms have not changed. In effect, people's behavior will change, so that social change will occur, following the behavior displayed by the law enforcers. If this condition happens, then social change is caused by the development of interaction between the community and law enforcement, not the law itself which brings social change.

However, if there has been a social change, the law must follow (even though the change was not caused by a change in law). This aims to meet the community's need for legal regulations that provide certainty. Moreover, in a society that is very complex, all actions of the community and law enforcement officials must be based on law. Therefore, if there are social changes, legal changes must also be made.

According to Teguh Prasetyo (Prasetyo, 2017), the legal change basically has several goals, in addition to meeting and following the social changes that have occurred. Changes in law among other things aim to eliminate laws that are out of date. Changes to the law are also carried out with the aim to reflect the values that have been accepted in society. In addition, changes to the law also aim to resolve the problems of injustice that have arisen in society. In this study, the intended legal change is a change in the meaning of the public interest in Indonesia.

The 1945 Constitution of the Republic of Indonesia (hereinafter referred to as the 1945 Constitution of the Republic of Indonesia), as the highest legal basis, stipulates that all agrarian resources in Indonesia are controlled and used for the greatest prosperity of the people. Consequently, the state is given so much authority to manage and utilize the agrarian resources. One form of state management is to carry out development, where the development will later be utilized to achieve the greatest prosperity of the people. 
This concept was revealed in the Land Acquisition Law, which contains 18 types of activities that fall within that public interest. Among the 18 types of development activities, the government then enacted Presidential Regulation Number 3 of 2016 concerning the Acceleration of National Strategic Project Implementation as amended twice by Presidential Regulation Number 58 of 2017 concerning Amendments to Presidential Regulation Number 3 of 2016 concerning the Acceleration of National Strategic Project Implementation and Presidential Regulation Number 56 Year 2018 concerning Second Amendment to Presidential Regulation Number 3 Year 2016 concerning the Acceleration of the Implementation of National Strategic Projects. In the presidential regulation, there are 227 national strategic programs, which are divided into 26 types of development activities. Among the 26 types of development activities, the construction of toll roads has become the most development program, with a total of 80 new toll roads, and spread in 16 Provinces. In connection with the Airport, there are 7 planned airport developments, with details of 3 airports being repaired, and 4 new airport developments, one of which is NYIA.

This research will discuss whether in a legal perspective, airport development is appropriate if it is included in one of the objects of public interest in Indonesia. This analysis will use the perspective that the law is considered capable of carrying out social engineering, so as to be able to make social changes as mentioned above. If the resulting social change does not lead to change for the better, then the law must be adjusted and replaced so that the change goes in the desired direction, and vice versa.

The issuance of an airport permit is considered capable of making enormous social changes for the community, especially the Kulon Progo community as the party affected by development. But it seems that social change is not leading to social change for the better. The resulting social change is precisely by changing the behavior of the people who initially farmed, into the patterns of life of people who do not farm. This social change is considered not heading for the better, because basically sustainable food agriculture land (LP2B) is absolutely necessary in an effort to realize food independence (Alan, 2019). Strictly speaking, food independence will not be achieved, when agricultural land decreases.

The social change above is evident from the large change in the number of farmers in Kulon Progo. According to the 2013 Central Statistics Agency (BPS 2013), the number of farmers in Kulon Progo is 88.68 thousand. This number is down from 2013 which reached 94.86 thousand. The same note from the Central Statistics Agency in 2018 (BPS 2018), the number of farmers in Kulon Progo only amounted to 86,660. Although it cannot be proven directly that the decline was due to the development of NYIA, the fact that the construction site of the airport where the community is farmers cannot be ignored. The farmer certainly lost his job as a farmer and was forced to leave his rice field.

As mentioned earlier, when the law is unable to bring justice to society because it is unable to bring social change for the better, then the law must be changed and evaluated. According to the authors, the law that must be evaluated is the determination of airports as one part of development in the public interest. 
In general, not only NYIA, airport construction should actually be considered not part of the public interest. The public interest, must be seen as the interests of the majority of the community, so that the interests of individuals (in the sense of landowners) must be set aside. As a result, when the interests of most people need land, the land that is owned by someone must be released.

This position, in fact places the public interest in such an important position. This concept can be used to take over a land right owned by someone. Whereas ownership of a land right is a basic human rights concept, and must be fulfilled by the state. And in this study, according to the author, the airport is not part of the public interest, in the sense of the interests of most people.

Indeed, the data from the Central Statistics Agency states that domestic aircraft passengers, the January-March 2019 period only" reached 18.32 million passengers (BPS 2019). This number is down 17.66 percent compared to the same period in the previous year, and is the lowest for the last 3 years. This number is certainly very large, compared to the total population of Indonesia in 2019 which reached 266.91 million people (BPS 2019). Looking at the calculations above, airplane passengers have almost reached 6 percent of the entire population of Indonesia.

However, keep in mind that the number does not reflect the actual conditions. It could be that the passengers of the plane are the same people, but have traveled by plane many times. This opinion is based on the fact that increasingly expensive (domestic) plane tickets. This condition is caused by the existence of 2 new rules set by the Ministry of Transportation (Kukuh Tejomurti, 2017: 102) The regulation is the Minister of Transportation Regulation No. 20 of 2019 about Procedures and Formulation of Calculation of the Tariff Limit on Passenger Economy Class of Scheduled Domestic Commercial Transportation, as well as the Decree of the Minister of Transportation No. 72 Tahun 2019 about Tariff Limit on Passenger of Economy Class Passenger Services of Domestic Scheduled Commercial Air Transport. The two rules changed the tariff for the lower limit of the plane, which was originally 30 percent, to 35 percent. For example, a plane ticket from City A to City B is 1 million rupiah. The lower limit tariff for the plane ticket was initially 300 thousand rupiah. However, after the two rules have been issued, the lower limit tariff will be 350 thousand rupiah. Strictly speaking, airline tickets this day are becoming increasingly expensive, and the impact is only some people are able to access them.

This condition is also supplemented by data that there are 9.41 percent of population in Indonesia. This number is equivalent to 25, 14 million residents as of March 2019 (BPS 2019). This number indeed decreased by 0.53 million people from September 2018 and decreased by 0.80 million people from March 2018. Still according to the Central Statistics Agency, the poor population is a population with an opinion per capita of 425,250 rupiah per month. This calculation shows that there are 25.14 million people who have a small possibility of being able to get access to plane tickets with prices for example 350 thousand rupiah. The number of poor people is also certainly greater than the number of airplane passengers, and further weakens the opinion that 18.32 million aircraft passengers are all different people. 
The entire description above shows that airport construction is basically not in the public interest. The phrase "the interests of most people" is not fulfilled because the airport is not part of the intended interest. However, that does not mean that the state is not allowed at all to build airports. The state is still allowed, though, not on the pretext of public interest. As a result, when the state needs land for airport construction, there is no obligation for landowners to release their land, because it is not part of the concept of social functions on land. In this condition, the relationship between the state and the land owner is no longer an unequal relationship where the state is higher than the land owner. However, both have the same position and equal.

This concept has 3 legal consequences. Firstly there is no obligation for landowners to release their land for airport development. Second, the price determination is agreed upon between the state and the land owner. Third, there is no consignment system in land acquisition for airport development activities as regulated in the Land Acquisition Act.

\section{Conclusion}

NYIA development to this day still leaves a structural agrarian conflict that has not ended. This conflict is caused by the absence of a good planning method, and violation of several legal provisions in terms of granting a construction site permit. This research analyzes using 2 scientific perspectives. First is the economic perspective and secondly the legal perspective. After the analysis using an economic perspective, it was found that the NYIA development did not meet the criteria for development that was able to realize economic efficiency. On the other hand, analysis using a legal perspective results in the finding that airport development should not be part of development in the name of the public interest. Consequently, there is no obligation for landowners to relinquish their land rights for airport development, pricing is determined jointly between the state and landowners, and there is no consignment system in land acquisition for airport development purposes as stipulated in the Land Acquisition Law.

\section{BIBILIOGRAPHY}

\section{Books:}

Adi Sulistyono and Muhammad Rustamaji. (2009), Hukum Sebagai Panglima (Economic Law As Commander). Sidoarjo: Masmedia Buana Pustaka.

Cento Veljanovski. (2007). Economic Principles of Law. United Kingdom: Cambridge University Press.

Soerjono Soekanto. (1980). Sosiologi Hukum (Principal Sociology of Law). Jakarta: Rajagrafindo.

Teguh Prasetyo. (2017). Pembaruan Hukum, Perspektif Teori Keadilan Bermartabat (Legal Renewal, Perspective of Dignified Justice Theory). Malang: Intrans Publishing. 


\section{Journals:}

Daniel S. Lev. (1971). The Supreme Court and Adat Inheritance Law in Indonesia. The American Journal of Comparative Law, Volume 11 Number 2

Kukuh Tejomurti. (2017). Right to Safety and Security for Passengers Traveling By The Public Road Transportation. Yustisia Jurnal Hukum Volume 6 Number 1

Louis Kaplow and Stevan Shavell. (2002). Economic Analysis of Law, Harvard Law School and National Bureau of Economic Research, Volume 3, USA

R.H. Coase. (1960). The Problem of Social Cost, Law and Economics. Volume 3.

Richard Posner. (1975). The Economic Approach to Law. Texas Law Review 757, University of Chicago Law School

\section{Paper:}

Muhammad Fikri Alan. (2019). Toll Road Development Is More Important Than Protecting Sustainable Food Agricultural Land (?): Criticizing the Concept of Public Interest in Indonesia, Thesis. Yogyakarta: Gadjah Mada University,

Report of the Central Statistics Agency 2013

Report of the Central Statistics Agency 2018

Report of the Central Statistics Agency 2019

\section{Websites:}

Anonymous, Kulon Progo (New Yogyakarta) Airport, in www.centreforaviation.com, accessed December 2, 2017

Anonymous, This Temon Residents Receive 170 M for Loss For Airport, www.nasional. tempo.com, accessed December 2, 2017

Anonymous, Farmer Kulonprogo Complains Action AP 1 Landline Problem Airport, in www. tirto.id, accessed December 3, 2017

End of Year KPA Year 2012-2018 entry in www.kpa.or.id, accessed on January,2 2020

\section{Legal Documents:}

The 1945 Constitution of the State of the Republic of Indonesia

Law Number 5 of 1960 on Basic Regulation of Agrarian Principles

Government Regulation Number 27 of 2012 on Environmental Permits

Regulation Of The Minister Of State Agraria / Head of National Land Agency Number 2, 1999 Concerning Location Licenses

Minister of Transportation Regulation Number 20 of 2019 on Procedures and Formulation of Calculation of the Tariff Limit on Passenger Economy Class of Scheduled Domestic Commercial Transportation,

Minister of Transportation Number 72 Tahun 2019 concerning Tariff Limit on Passenger of Economy Class Passenger Services of Domestic Scheduled Commercial Air Transport 